Kansas State University Libraries

New Prairie Press

\title{
Perceived Best Practices for Faculty Training in Distance Education
}

Michael G. McVey

Follow this and additional works at: https://newprairiepress.org/aerc

Part of the Adult and Continuing Education Administration Commons

(c) (i) (8)

This work is licensed under a Creative Commons Attribution-Noncommercial 4.0 License

\section{Recommended Citation}

McVey, Michael G. (2014). "Perceived Best Practices for Faculty Training in Distance Education," Adult Education Research Conference. https://newprairiepress.org/aerc/2014/roundtables/21

This is brought to you for free and open access by the Conferences at New Prairie Press. It has been accepted for inclusion in Adult Education Research Conference by an authorized administrator of New Prairie Press. For more information, please contact cads@k-state.edu. 


\title{
Perceived Best Practices for Faculty Training in Distance Education
}

\author{
Michael G. McVey \\ Pennsylvania State University
}

\begin{abstract}
Keywords: learning style; best practices; distance educators; online teaching; transformative learning theory
\end{abstract}

\begin{abstract}
After conducting a literature review of adult student learning styles and teaching method analysis, it became apparent that there was not a significant difference in academic performance for students with differing learning styles whether they attended face-to-face or online classroom environments. What was not clearly indicated though, from the review of the literature, was what were the perceived best practices for online teaching from the perspective of experienced distance educators and whether the instructors' perceived learning style was incorporated in training programs to assist faculty to teach online. Thus, the purpose of this qualitative pilot study is to determine the perceived best practices to train faculty to teach in an online environment and how individual instructors' perceived learning styles can be incorporated within best practices to foster competence on an individual instructor level. This study also analyzes faculty resistance to distance education and how transformative learning theory may play a role in overcoming this resistance.
\end{abstract}

Findings

Upon completion of semi-structured interviews, three themes emerged. They are described below as part of a data display:

\section{Qualitative Data Display of Findings}

- Instructor Readiness for Teaching Online

- $\quad$ Online Course-The Magic is in the Redesign

- $\quad$ Students Pursuing Education Online-Be Realistic

\section{Instructor Readiness for Teaching Online}

In terms of participant perceptions of best practices for training faculty to teach online, the common theme was the online tools each institution made available to its faculty to learn to teach online and to address faculty resistance.

\section{Online Course-The Magic is in the Redesign}

When looking at the perceived best practices to train faculty to teach online, one of the common themes surrounded the course design. How did the course meet the learning outcomes for the students? When designing a course, the participants did consider the teaching philosophy of the instructor but only to the extent it led to determining what was the best way for students to learn. To accomplish this, redesign of the online course may become necessary. The "magic is in the redesign". 


\section{Students Pursuing Education Online-Be Realistic}

When considering the biggest challenges with online learning from a students' perspective, students needed to be realistic about their expectations when taking a course online and also to address their fear of technology.

\section{References}

Allen,E., \& Seaman, J. (2013). Changing course: Ten years of tracking online education in the United Sates. Babson Survey Research Group, 1-42.

Cranton, P. (2006). Understanding and promoting transformative learning. San Francisco, CA: Jossey-Bass.

Gaillard-Kenney, S. (2006). Adjunct faculty in distance education. What program managers should know. Distance Learning, 3(1), 9-16.

Grandzol, J. R., \& Grandzol, C.J. (2006). Best practices for online business education. International Review of Research in Open and Distance Learning ,7(1), 1-12.

Irani,T., Telg, R., Scherler, C., Harrington, M. (2003). Personality type and its relationship to distance education students' course perceptions and performance. Quarterly Review of Distance Education,4(4), 445-453.

Merriam, S.B. (2002). Qualitative research in practice. Examples for discussion and analysis. San Francisco, CA: Jossey-Bass.

Merriam, S.B. (2009). Qualitative research. A guide to design and implementation. San Francisco, CA: Jossey-Bass.

Mezirow, J. (1994). Understanding transformation theory. Adult Education Quarterly, 44(4), 222-232.

Ratcliff, D. (2008). Qualitative data analysis and the transforming moment. Transformation: An international journal of holistic mission studies, 25, 116-133.

Steinbronn, P.E., Merideth, E.M.(2007). Perceived utility of methods and instructional strategies used in online and face-to-face teaching environments. Innovative Higher Education, 32, 265-278.

Taylor, E.W. (2008). Transformative learning theory. New directions for adult and continuing education. 119, 5-15.

Ugur, B., Akkoyunlu, B., Kurbanoglu, S. (2011). Students' opinions on blended learning and its implementation in terms of their learning styles. Education Information Technology, 16, 5-23

Williamson, M.F., Watson, R.L. (2007). Learning styles research: Understanding how teaching should be impacted by the way learners learn part III: Understanding how Learners' personality styles impact learning. Christian Education Journal, 4(3),6277.

Wolf, P.D. (2006). Best practices in the training of faculty to teach online. Journal of Computing in Higher Education, 17(2), 47-78. 